\title{
Undoing the sleights of hand: Prophets and scholars - two mythic discourses
}

\author{
Gerhard van den Heever \\ Department of New Testament \\ University of South Africa
}

\begin{abstract}
By comparing the historical recalibration of the myth of the Mother of the Gods in Athens with the scholarly construction of the mysteries in nineteenth and twentieth century religio-historical scholarship, this essay argues that just as primary practitioners of religious discourse engage in religious mythmaking, so too do scholars of religion. Both the practice of religion and scholarship on religion subsist in the political domain of social discourse and mythmaking. However, the two kinds of mythmaking are not simply identical. It is the distance to the discourse afforded the scholar that enables scholarship as politically committed denaturalisation, or historicisation, of religious tradition and reflexive scholarship.
\end{abstract}

"Isn't scholarship just another instance of ideology in narrative form? Don't scholars tell stories to recalibrate a pecking order, putting themselves, their favorite theories, and their favorite people on top?" ... "Isn't logos just a repackaged mythos?" ... to which I now respond: 'If myth is ideology in narrative form, then scholarship is myth with footnotes."'

(Lincoln 1999:209) ${ }^{1}$

\section{SITUATING REFLEXIVE DISCOURSE}

Religio-historical study of early Christianity is currently characterised by intellectual ferment that has far-reaching consequences. This is partly due, arguably, to seismic shifts in the study of religion with new theories, new re-

\footnotetext{
${ }^{1}$ The citation is from the "Epilogue: Scholarship as myth" and preserves a dialogue with an astute student questioning Lincoln's narrative of the scholarship on myth as itself another instance of myth, which on reflection prompted the answer "scholarship is myth with footnotes."
} 


\section{Undoing the sleights of hand}

evaluations of older theoretical work and scholarly traditions, and generally, new applications of these to fields previously insulated from these developments and study fields, gaining currency in academic discourse. The discipline New Testament Studies, of course, did not remain unaffected. While the development of new methods of reading New Testament texts has been an important feature in scholarship of the last three decades or so, increasingly the discipline itself is being reconceptualised so that more and more, New Testament studies is reconfigured as early Christian studies, with all the attendant implications pertaining to such a revisioning. Moreover, academic discourse is increasingly characterised by rigorous self-reflexivity, so that the processes of inquiry themselves become part of the object of inquiry, and in fact, help constitute the primary object of inquiry, which in our case is early Christianity. The argument pursued in this essay takes issue with these broader developments and the intellectual context in which inquiry into early Christianity takes place. This essay originated as part of a research seminar held in the Department of New Testament on the topic "New Ways of Inquiry into Early Christianity". 2 The context in which these deliberations were set, is created by two distinct, yet related, elements announced in the theme of the seminar, namely "New Ways of Inquiry", and "Early Christianity". On the face of it, the first clearly denotes the type of discourse pertaining to a meeting such as this, namely this is a reflection on the nature of scholarly or academic inquiry. The second phrase evokes the field of practice of a living religion, Christianity, and in particular, the early formative stages of Christianity. The first implies a rupture in analytical praxis, though in the suggestive form of "new ways", an announcement of a new/different politics of analysis. The second already betrays an ideological orientation, namely that the disciplinary praxis concerns itself with a historical phenomenon primarily. ${ }^{3}$

The formulation "field of practice of a living religion" is deliberate. It points to the fact that the study of religion derives, for the most part, its justification from the world-making, socially formative, and culturally symbolising effect of this particular discourse we ordinarily label "Christian religion". ${ }^{4}$ That we adduce significance to the early formative stages of

\footnotetext{
${ }^{2}$ The seminar was held on 17 May 2007 at the University of South Africa, and the programme consisted of four papers: Jurie H le Roux, "The possibilities and challenges of New Testament scholarship in South Africa"; Gerhard van den Heever, "Undoing the sleights of hand:

Prophets and scholars - Two mythic discourses"; Johannes N Vorster, "The rhetoric of the body and its usefulness for the study of early Christianity"; and Pieter J J Botha, "Considering 'religious life' in the world of the early Christians".

${ }^{3} \mathrm{~A}$ view I am sympathetic of, although I also want to extend the conceptualisation of the issue into a somewhat more encompassing discourse analysis and theorising.

${ }^{4}$ This hold true, even when Christianity is studied in institutional settings that on the face of it purport to practise "neutral" study of religion (see the article by Don Wiebe referred to below). For the greater part of the institutionalised disciplinary study of Christianity, a theological base ideology governs the disciplinary praxis.
} 
"Christian religion" (i. e. to the period delimited by the corpus of Christian writings now canonised as "New Testament", roughly the late first century CE, or the "earliest church") is equally instructive, for this is not a natural given. Rather, it is the result of a particular set of cultural and historical developments not shared with the greater part of the history of the Christian tradition, nor with a very sizable section of contemporary Christian communities. It is, in addition, by now a truism to refer in this regard to the effects of Renaissance (and Reformation period) and early Modern calls for humanist, historicist interpretation of religious tradition, "ad fontes", and which formed the groundswell of the later (in the Occidental world) so dominant mode of inquiry: "historical" in its many manifestations - historicalgrammatical, historical-critical, religio-historical, socio-historical, et cetera. In short, neither the delineation of the object of study, Christian religion, as a substantive phenomenon, nor the focus on the period of origins as definitive, or even the requisite appropriate methodology for studying early Christian discourse, is a natural given. So, when viewed from a wider perspective, the issue that announces itself, is this: what defines the essence of a religious tradition, and on what grounds do we determine what this essence is? As well, what is the proper interpretive or analytical stance towards any such construction or imagined religious formation, and what purpose is served by such interpretive or analytical practices?

The answers to these questions are quite diverse, depending on the ideological position and localisation of the person who has to judge: it can range from an appeal to some (significant or canonical) stage of the history of that religious tradition, mostly/often the oldest phase of the originary vision (in our case, early Christianity or the New Testament period); or a particular canonical section of the tradition (e.g. Theravada vs Mahayana Buddhism, Protestant mainstream vs Catholic or Pentecostal Christianity); or it may include the whole of the developing tradition, inclusive of everything produced in its name, even so-called heterodox traditions (which term in this framework, of course, loses its explanatory meaning) (Pye 1973:1-58). However one wants to view the essence of the Christian tradition (to stay with only the one tradition forming the focus of this discussion), fact is our view (and here I mean both the view of practitioners of religion, as well as reflexive scholars of religion) is shaped not only by the particular position we occupy vis-à-vis the tradition, but also by the way the tradition has come to define itself in ever shifting and differentiating fashion during the long process of being continually moulded by the vicissitudes of its historical trajectories (Pye 1994; 2000). To put it in the terms now made fashionable by Eric Hobsbawm and Terence Ranger, religions are invented traditions (Hobsbawm 1983:1-14). Invention in this context denotes the rhetorical techniques involved in creating, 


\section{Undoing the sleights of hand}

establishing and maintaining myth; the rhetorical nature of the construction of a narrative of identity; the selection of narratives and "pasts" from which to manufacture a history and world orientation; the arrangement of the narratives; their contextualisation and imbuing with values and importance and significance (Van den Heever 2004:208). In short, the formation of a religious tradition is a mythmaking enterprise.

Yet, Christian religious discourse is characterised and supported by claims to superhuman and supernatural origins - it is a revealed religion, that is, on its internal claims it is a sui generis discourse. Thus, Christian religious discourse speaks with a transcendental authority that is not derived from, and that is removed from, the contexts and forces that shaped its variable manifestations, even though all religious imagery and discourse, on the face of it seemingly innocuous, have social and political implications as symbolic speech acts and interventions (Lincoln 1983:151). To speak with such transcendental authority, the practitioners of religious discourses need to perform a sleight of hand, and this, quite simply, consists of transforming Culture into Nature, of occluding the cultural manufacturedness of itself and projecting itself as always having been thus, that is, as the (pre-)ordained nature of things characterised by the necessity of being just so. It resides in the occulting of the time-bound mutability or malleability of particular discourses in favour of eternal perspectives, immutability sub specie aeternitatis. As Bruce Lincoln puts it:

... myths are not sacred narratives. Although many myths claim sacred status, in this they misrecognize their own nature, for they are human stories, like any other. They simply make more exaggerated claims to a more elevated kind of authority ... myths are not collective narratives or the speech of any group as a whole ... in its details each variant advances the specific interests of those responsible for its production, revision, and circulation. These anonymous agents and absent authors misrepresent themselves and those for whom they speak - as the group as a whole ... myths are neither false stories, nor true, but simply stories that claim to speak with authority about issues of deep importance.

(Lincoln 2006:242)

Announced, therefore, in the theme "New Ways of Inquiry into Early Christianity", is a clash between two seemingly incompatible ways of speaking, namely one which resides in history and the other in eternity, the one emanating from the domain of culture, the other from the domain of 
Nature. As Bruce Lincoln (2005:8) puts it in the first three of his (now quite famous and oft-quoted) "Theses on Method", especially no 3 :

\begin{abstract}
History of religions [as a method - GvdH] is thus a discourse that resists and reverses the orientation of that discourse with which it concerns itself. To practise history of religions in a fashion consistent with the discipline's claim of title is to insist on discussing the temporal, contextual, situated, interested, human, and material dimensions of those discourses, practices, and institutions that characteristically represent themselves as eternal, transcendent, spiritual, and divine.
\end{abstract}

Scholarly study of religion as a historical discipline has thus as its aim to denaturalise religious discourse and its attendant claims (or perhaps better, to historicise it), which is why scholarship on religion is concerned with such questions as the rhetoricity and embedded interestedness of ("religious") symbolic interventions and projections (Lincoln 2005:8-9).

However, the picture is more complex, as suggested by thesis numbers 7 and 8 of Lincoln:

when scholars equally participate in portraying cultural and religious traditions as monolithic, harmoniously integrated social formations and religious discourses, as unchanging and stable traditions, and in doing so, replicate the ideological positions of privileged informants as if these voices speak for all the adherents of the given (section of) the tradition, scholars too transform a historic narrative into a religious one. In such a context scholarship becomes an apology for a transcendent ideal.

(Lincoln 2005:9)

This is what has happened for the greater part of modern scholarship on early Christian literature and the history of early Christianity. By taking as orientation principle the picture of Christian origins of Luke/Acts and Eusebius (the so-called "big bang" theory) and merely paraphrasing them, without considering deconstructing these with the aid of new theories of religion, discourse, and myth, generations of church historians and scholars of Christian religion remained captive to the rhetoric of Luke and Eusebius. In doing so, they merely ventriloquised the ideology and rhetoric embedded in these so foundational texts (Mack 2001:60). And yet there is more: even when the conventional picture of Christian origins was called in question by the new historical-critical and religio-historical methods of scholarly investigation into Christian origins and history, the "new history" was itself beholden to the 


\section{Undoing the sleights of hand}

mythmaking interests characterising its period of birth and maturation (Van den Heever 1993:20-27). ${ }^{5}$ The ruptures in the interpretive tradition represented by the complex Renaissance-Reformation-Modernity (and now: Postmodernity?) were not occasioned from outside of the field of religious production, but rather were the result of recalibrations within the religious field of "first-order myth". One can safely say that reimagining or redescribing Christian origins, or the countering of this in faith-serving academic work, is not so much a question of establishing the truth of "what really happened" as it is a social and political positioning vis-à-vis other groups and social formations drawing on different versions of myth and symbolic interventions (the political use of myth that Bruce Lincoln talks about, the clearest statement of this is in Mack [2001:177-199], "The Christian myth and the Christian nation"). Insofar as this social and political positioning is occluded, scholarship constructs itself as a species of mythmaking.

\section{TWO MYTHIC DISCOURSES}

The dual aspects of scholarship as myth on the one hand, and of the imposition of a "primary, originary" mythic discourse on the other, both as constitutive elements of social, cultural, and religious construction, announced in the cited epigraph, constitute the two poles straddled by the argument pursued in this essay. At heart "the troublesome and arduous work of imagining social formations and religious "constitutions"' in the context of religio-historical study is first and foremost concerned with the "field of scholarly production" (to coin a phrase in imitation of Pierre Bourdieu) as the matrixed - and "martricising" - collection and representation of social-religious data, and secondarily, with the imagining into being of religious social formations or institutions (or "constitutions" as I put it here) on the level of "everyday practice" (the quotidian toil of religious production, or the champs religieux Bourdieu talked about). Bourdieu has long pursued the making of a "reflexive sociology" which brings into purview both the object of perception/knowledge and the act of constructing the object. The "field" refers to the social circumstances conducive to, contributing to, and giving embodied form to the cultural artefacts produced within that context. As such the "field" also encompasses the embodied ideologies-in-contest and the interests of both producers of myth and religious discourse and authority, and the consumers/recipients of such religio-socio-cultural production (see inter alia

\footnotetext{
${ }^{5}$ See also Mali (2003) for how the modern shape of history as both narrative and as academic discipline derives from mythic imaginings in the course of the 18th and 19th to early 20th century.
} 
Bourdieu 1968; 1984; 1988; 1992; 1993; and for a discussion of the term in Bourdieu, see McNay 1999:95-117).

What is important to keep in mind, though, is that these two - scholarly production and the imagining into being of religious social formations or institutions on the level of "everyday practice" - are not separate nor separable aspects of the scholarly toil, but the proverbial obverse and reverse of the same coin, not only mutually implicating each other but each existing insofar as it makes the other possible. They are each other's enabling condition. But even this is too simplistic, for "everyday (religious) practice" is simultaneously folk practice and folk tradition on the level of popular religion, ${ }^{6}$ the result of embodied mythmaking and performance as discourse construction and maintenance ${ }^{7}$ as well as the generative structuring of the habitus by the "mobilizing agents" in any social and cultural formation (Bourdieu 1977:78; McNay 1999:99, a reference to Pierre Bourdieu [1990], The logic of practice). "Disposition" or dispositif, a term related to habitus, is the rule generated, socially constructed affectively-laden body as medium for or site of the socially locative powerplay that occasions and arranges the positions occupied by the relevant embodied person and the resultant performances that go with the particular position. ${ }^{8}$ Included in the category "mobilising agency", and only to focus for the purposes of this study on the field of religious production, one should see of course, are the multi-levelled and multi-hierarchised complex systems of authorising, spanning a continuum of horizontal and vertical relationships running from significant others such as parent vis-à-vis child, members of religious groups among themselves, local minister/priest/religious expert vis-à-vis local community, religious hierarchy or institutional bureaucracy, theologian-as-authoritative-insider-commentator, and the scholar-as-authoritative-analyst/theoriser. Each of these authorising institutions occupy a different and differentiated position in the social and

\footnotetext{
${ }^{6}$ I mean this in the most generalised sense possible, as "what people do". I am not intending an analysis of the terms "folk", or "popular religion", and fully aware of the nebulous and artificial character of these terms, I nevertheless use them to indicate the most general and basic field of religious toil, where "religion" is interwoven with the quotidian, the ordinary human ways of doing things.

${ }^{7}$ Bourdieu's habitus, the embodied rules of - or better, rule conformance to - the social and cultural game/s: "a system of durable, transposable dispositions that mediates an individual's actions and the external conditions of production".

${ }^{8}$ Bourdieu (1977:81): "The habitus is precisely this immanent law, lex insita, laid down in each agent by his [sic] earliest upbringing, which is the precondition not only for the co-ordination of practices but also for practices of co-ordination, since the corrections and adjustments the agents themselves consciously carry out presuppose their mastery of a common code and since undertakings of collective mobilization cannot succeed without a minumum of concordance between the habitus of the mobilizing agents (e.g. prophet, party leader, etc) and the dispositions of those whose aspirations and world-view they express."
} 


\section{Undoing the sleights of hand}

religious field, each position marked by different investments from behaviour control and training (the inculcation of dispositifs and habitus through systems of education), to straightforward advocacy (religious ministries and theology), to reflexive and analytical praxis.

My argument is thus that both scholarly study of religion and the practice of religion are species of discourse and discourse-making, and therefore that both - although not of the same order - subsist in the political arena of social discourse and social formation. The exact distance of scholarship on religion, and religio-historical study, from the "everyday practice of religion" is the matter of contention. With particular sharpness Donald Wiebe has argued that the study of religion is/must be "a social science that must strive, as all scientific endeavor, to be free from religious, political, and ideological determination" (in reaction to Paul J Griffith [1999] Religious reading: The place of reading in the practice of religion) (Wiebe 2001:334). According to Wiebe, in spite of pretensions to the contrary, even in learned societies such as the American Academy of Religion with its profession of "a nonreligious scholarly agenda in the study of religion in the academic context" the presidential addresses to the Academy demonstrated the "message' of its official leaders was indistinguishable from the religiously orientated messages of the presidential addresses delivered to the NABI (i.e. National Association of Bible Instructors - GvdH) ... precisely the kind one finds in formal theological contexts" (Wiebe 2006:275). Even phenomenological studies of religion are characterised by an essential religious nature (see the extensive discussion in Flood 1999).

This is not to say that scholarly study of religion and the practice of religion are to be identified in a facile manner (or in fact, can be), but merely to point out that scholarly discourse and analysis is equally not born sui generis, but generated in the crucible of political kairos, beholden to social ideologies, and committed to particular stances vis-à-vis discursive contexts. The history of the emergence of the scholarly study of religion, "science of religion" (Religionswissenschaft), provides ample evidence of this, and to demonstrate this I will furnish two examples of the political nature of both religious mythmaking and scholarly mythmaking.

\section{ON DISCOURSE AND IDEOLOGY}

I use the term "discourse" in a slightly more expanded sense than the definition given in Tim Murphy's article "Discourse" in the Braun/McCutcheon Guide to the study of religion (Murphy 2000a). In my usage, discourse is a simultaneous combination of a number of aspects. Discourse is the contents of a set of representations, whether linguistic, textual, or otherwise symbolic 
(including ritual), characterised by a domain of topics that lends it some kind of identity (identified as such by the classificatory and taxonomic activity of the interpreter or "reader of discourse"); but discourse also includes the social location that forms the originary matrix for the particular invention of the set of representations; and it includes the social interests encompassed/ encapsulated in and giving rise to the set of representations; and it includes the logic governing the interrelations between these factors or aspects, as well as the institutionalisation of such "domained" representations in canons of tradition, schools of thought, habitus as habituated action, cultural and sociopolitical-economic conventions, that is, as discursive formations. However, even though the phrase "originary context" may evoke singular, identifiable origins, discourse is a multivalent and "multi-origined" set of representations "discourse comes from everywhere" as Judith Perkins once put it. Discourse, in effect, is the result of an ensemble of representation genres, from texts, rituals, everyday habits, traditions, state machinery and their function, high culture-low culture, entertainment, bodily dispositions and habitus in general, the built environment, et cetera. To understand discourse like this, means that to "read" discourse is to read it self-reflexively, namely in the consciousness and awareness of the interest-ladenness of the constructedness of the set of representations, as well as of the fact that the "reading of discourse" is itself a further instance of discourse, determined by its own set of terministic screens, social location, and social interests and logic. "Discourse reading" is therefore a multileveled activity, on both primary (first order) level and on the secondary (second order) level, to put it at its simplest. If one understands the reading of discourse to also be discourse then it should also be clear that the distinction between first order and second order of discourse is somewhat misleading. In a sense there is only first order discourse, or equally true, there is only second order discourse, since each discourse as a kind of language is a speaking of that language in the context of another language (Murphy 2000b).

So, to sum up: discourse is the sum of the institutionalised, multiorigined set of representations, originating from social interests shaped by a certain social location, governed by a logic that binds it together into an identifiable identity, and "read" within the context of another discourse. If the issue at stake is the contest between discourses of Culture and Nature, of historicisation and mythmaking, then it is equally clear that we are dealing with scholarship and religious mythmaking as ideological realities.

In the course of history two main lines of thinking about ideology have emerged: the first is the "original" interpretation originating from Destut de Tracy, running via Marx and Engels, via the revolutionary movements of the $20^{\text {th }}$ century, and operative in thinkers such as Althusser and even Habermas. 


\section{Undoing the sleights of hand}

This is the line that takes ideology to be the tool by which a hegemonic class occludes the operations of its exploitation of those members of society on lower power rungs of the social ladder. It is typically located in so-called "ideological state apparatuses", and ideological critique means to unmask the processes of oppression at work. While there is much to say for this, and in a study of variable resistances to imperial regimes such as Christianity within the Roman Empire, where the imperial cult (not solely, but pre-eminently) played the role of an "ideological state apparatus", this is an important facet of our understanding of the interplay of forces, nevertheless I prefer the more neutral interpretation of the term. This second line of thinking is to an extent embodied by Foucault, but see also the literature listed in Gary Lease's essay "Ideology" in Guide to the study of religion (Lease 2000), as well as the work of Bruce Lincoln, and such Marxist literary critics as Terry Eagleton. Taking my bearings from this cluster of theorising I see ideology as a general characteristic of all social existence and communication. Ideology in this sense denotes the way in which all action, representation, and communicative interchange - thus, all social existence - are beholden to the interests we pursue as we jockey for position in the acquisition of cultural and social capital goods ("Society is a field of tension" - Bruce Lincoln). All (unreflexive) discourse is ideological in that it naturally or intuitively occludes the material basis of its existence, or the conditions for its existence - we tend to assume that the way we see and give value to reality is how things are, and then act on this projection of world in the construction of our world. Ideology in this sense needs to be distinguished from downright lying and cynical manipulation, although ideologues can be guilty of these as well. Lying and manipulation implies wilful and deliberate misrepresentation and misleading, and thus the deception is conscious, mostly. When myths and rituals are transmitted and enacted ostensibly for the symbolic meaning but, on closer inspection, for the maintenance of power/authority hierarchies, then they function as ideologies, and are then properly classified as ideological discourses. Such is also the case with textualised traditions, or with rhetorical interventions. Gary Lease formulated it thus: "All religion is ideology, but all ideology is not religion" (Lease 2000:445). He wanted to negate the place of such ideological systems as Marxism, Nazism, et cetera. in the class of phenomena that make up religion, but of course there is a lot of debate in scholarly circles on this point of definition to which I do not endeavour to give an answer here. The point I am making is that even as mythic discourse (i.e., that which characterise religious speech) is ideological, so too is scholarship on religion. 


\section{ON RELIGION: THE RECALIBRATION OF MYTH - CYBELE/MAGNA MATER IN ATHENS}

As an example of the earlier mentioned socio-political recalibrations within the religious field of "first-order myth", I want to refer to the recent work by Mark Munn (2006), The Mother of the gods, Athens, and the tyranny of Asia: A study of sovereignty in ancient religion (A Joan Palevsky Book in Classical Literature) on the introduction of Cybele/Magna Mater in Athens in the fifth century BCE. ${ }^{9}$

The core argument of Mother of the gods deals with the circumstances surrounding the introduction of the cult of Cybele/Meter Megale (or, Kybaba/Kybebe, as she was known in Phrygia and Lydia) in Athens, from her initial rejection at the beginning of the fifth century to her arrival in Athens in the last decade of the fifth century BCE. Tracing these developments mainly through the eyes of Herodotus (but also other Greek writers - historians, poets, dramatists - as well as later writers from the imperial age and even later Antiquity, Munn sketches a picture of an ambiguous divinity whose shape and symbolic function are determined by the fluid historical, cultural, and political discourses that encoded the variously shifting Athenian and Greek adaptations to the flow of events in which they were caught up. In chameleonlike fashion the "Mother" is variously Mother of the gods; consort of the chief deity; consort of the sovereign; fertility deity; seductress; virgin; upholder of customs, laws, and constitutions; and bearer of many masks across different religious cultures from ancient Persia, Media, Babylonia, Assyria, Lydia, Phrygia, lonia to Attica and the Peloponnese. But it is exactly this facet that opens a window onto the discursive manufacturing of gods and its ideological underpinnings, and which Munn expertly uncovers in the course of his historical narrative and analysis.

Munn argues that the Mother of the gods formed the focal point for, and embodiment of, discourses about an ideology of tyranny and sovereignty (basileia) that ordered power relationships and was used in the construction of communal identity, worldview, and religion itself. Its first clear manifestation is seen in the eighth century BCE (Homeric epoch) Lydian kingdoms of Midas and Croesus, which inaugurated a legacy of tyranny understood as transgressive excess signifying divine justification of tyrannical rule. Not limited to Lydian and Phrygian political and religious culture, tyranny also marked the political culture of Greeks on the mainland and elsewhere. However, the fall of the Lydian kingdom to Achaemenid Persian hegemony, and the adoption of the ideology of tyranny by the Persians, forced a Greek

\footnotetext{
${ }^{9}$ I am drawing here on my review of Munn's book for Review of Biblical Literature (Van den Heever 2007).
} 


\section{Undoing the sleights of hand}

reconsideration of how to respond to the aggressive claims of Persian sovereignty. While Greeks were not unfamiliar with tyrannical regimes of their own, the "Persian situation" opened up a space for debates about the nature of sovereignty and the institutionalisation of sovereignty in communal institutions rather than vesting this in powerful personalities, developments which saw Lydian-Phrygian-Persian style tyranny acquire the character of odious oppression in Greek representations of power exercise. In this process a key role is played by the symbols of authority, the gods, and how they were appropriated, rejected, and used.

The central event that defined the Athenian reaction is the account of the murder of the ambassador sent by Darius to Athens demanding recognition of Persian sovereignty, the Metragyrtes (= "beggar of the Mother", the eunuch priest of the Mother of the gods at Sardis), which event unleashed a century-long history of revenge, warfare, shifting alliances (Athens, Sparta, the Ionian Greeks, even with the Persian satrapy in Asia Minor), and even intermittent peace treaties between sometime enemies. It is in the Athenian construction of the event - itself a fluid phenomenon - that the mythicising processes of interpretation of the significance of historical actions can be detected (the "political uses of myth," so Bruce Lincoln): the choice for "the gods of the Greeks" as rallying cry for the construction of Greek or panHellenic identity in contra-distinction to the earlier regnant encompassing "pan-Asian" worldview; the construction of Europe and Asia as mutually exclusive identities; the recalibration of Greek gods (or Greek versions of the Mother) to embody opposing characteristics disallowing constructions of tyranny (features such as virginity in contrast to emphases on sexuality); yet, gradually, also the adoption of the Great Mother as act of appeasement for the murder of her ambassador in answer to the various calamities befalling Athens in the long conflict with Persia; the introduction to Athens of the cult of the Mother as Aristoboulē, guarantor of "wise counsel" (i.e., as symbol of democratic deliberative harmony); and as the ever-ambiguous embodiment of both Greek aversion to tyranny as well as the recognition of the power and ideology of tyranny as underlying and feeding the Athenian empire in the exercise of its sovereignty and dominance of the Aegean Sea as maritime power. The Mother of the gods was an irresistible power (as Nemesis and Themis; as patron of sovereignty and carnivalesque nurturer, Demeter, Aphrodite, Rhea, and $\mathrm{Ge}$ ) that had to be defined and controlled.

The march of the Great Mother through the Mediterranean world spans a long history. It starts with the deep-reaching roots of classical Greek conceptions of sovereignty and tyranny in seventh and sixth century Asian mythologies of power centred on Sardis and Gordium (the centres of the 
Phrygian and the Lydian empires), and evidenced in the royal ideologies of the dynasties of Midas and the Mermnads (the dynasty of Croesus) with their mythologisation of the transgressive excesses of divine-human rulers as harbingers of paradisal wholeness and carnivalesque excess in a kind of Saturnalian golden age, with the concomitant spread of the Mother of the gods through the then-known oikoumene as the symbolic embodiment of the ideology and practices of Lydian tyranny. In the growing tensions and conflicts between Greeks and the kingdoms of Asia Minor, and then with the successor to the Lydian and Phrygian kingdoms - the Persian empire, the Mother of the Gods and attitudes towards her cult formed the focal point for the construction of mutually exclusive worldviews and identities of Asia and Europe and the division of the oikoumene into two separate domains of sovereignty. The bar was raised with the establishment of Persian sovereignty in Asia Minor and Persian appropriation of the ideology of Lydian tyranny and the effects this had on Persian-Greek interaction clearly delineated the various ways in which Greek recalibrations of divine identities answered developments in the political sphere. This is clearly demonstrated by the rhetoric operative in Herodotus's account of the history of the introduction of the Great Mother to Athens as interwoven with his own analysis of the presence and effects of the hand of the god in the political vicissitudes of Athens as an element in the construction of Athenian self-awareness of their own "imperial" place in the oikoumene. When finally the Great Mother was introduced to Athens and incorporated into the society of city cults, it was in a very different guise to the way in which Greeks initially had got to know her as Asian goddess - now recalibrated with different characteristics, providing evidence of an Athenian accommodation to a world in which they shared sovereignty with Persian Asia. Thus the introduction of the cult of the Mother in effect constituted a kind of "religious peace treaty" with the Persians of Asia Minor.

A similar recalibration took place almost three hundred years later, in a Rome embroiled in a war with Carthage. The Roman transportation of the Great Mother (in the shape of her image, the black meteorite stone) from her home seat at Pessinus in Phrygian Galatia at the height of the second Punic war took place equally at a time of ambiguous evaluations of the outcome of the war, during a struggle for maritime supremacy (on Magna Mater in Rome, see Turcan 1996:28-74). This fact is significant in that it exhibits a similar appropriation to the Athenian recalibration of the Mother. That the Mother and her cult was severely constrained and controlled in Rome in an effort to contain the excesses associated with her cult, speaks volumes for dual Roman awareness of her efficacy in enabling imperial formation and control of the sea (as in the case of Athens two centuries before), as well as the 


\section{Undoing the sleights of hand}

temptation to tyrannical power grabs inspired by the Mother - to be contained by the Republic still nominally beholden to democratic ideals (again, reminiscent of Athenian praxis of two centuries before). And in this the subsequent history of Rome is very much a replication of the attitudes and practices in contestation in Athens, as well as of the eventual fate of Athens and its democratic discourse.

The "triumphal march of Isis" through the Mediterranean world (Versnel 1993) illustrates the ambiguities embodied by imperialised female deities even better: as represented in the Kymean aretalogy (IK Kyme 41) Isis is both tyrant and the destroyer of tyrants; both deliverer from tyranny and binding devotees in bonds of exclusive loyalty; as tyrant controls the sea and fate; and gives civilisation and the fruits of agriculture to the human race. As civiliser, as tyrant, as guarantor of a restored paradisal age, Isis indeed comes to function as an "Egyptian Great Mother", something further demonstrated by her character as myrionyma - all the other female deities embodied. And it is no coincidence that she assumes the position of tutelary deity to the Flavians after 69 CE and remained the symbol of the presence of Roman sovereignty on the borders of the empire, a political formation the justification of which was premised on the restoration of the saeculum aureum, a mythical golden age. When later the virgin, the mother of God, God-bearer "Theotokos", Queen of Heaven assumed a similar position in the Christian empire we can discern the remarkable persistence of myth in the eastern Mediterranean world from the seventh century BCE to the present day, variously expressed and represented to be sure, but with a consistency of ideology and symbolism that is truly remarkable. ${ }^{10}$

The history of the Mother of the Gods elegantly illustrates how ancient divinities were not static types, but rather expressions of cultural systems that responded to historical change, and through this the very important issue of the connection between religion, cosmogony and politics is raised. The way a society conceives sovereignty in the religious domain must be related in some way to the way it conceives sovereignty in other domains, as in politics.

\footnotetext{
${ }^{10}$ On the development of the "imperial" Marian ideology, see especially Limberis (1994).
} 


\section{ON RELIGIOUS SCHOLARSHIP: THE MYTH OF MYSTERY RELIGIONS - CONCEIVING MYSTERIES AS MIRRORS OF CONTEMPORARY RELIGIOSITY ${ }^{11}$}

If "primary practitioners of religious discourse" can appropriate and recalibrate myth in a process of symbolic intervention as part of social discourse, religious scholarship, even scholarship purporting to be "historical-critical", can similarly engage in appropriation and recalibration of myth, and thereby practise remythologisation, themselves thereby practising a kind of "first order mythmaking". Mysteries/mystery religions - in the context of the history of religious scholarship a very special case and "discovery" of the religiohistorical scholarship of the nineteenth century - have had a fascinating career path through religious scholarship the past one and a half century. In the process the mysteries were transmogrified into contested images of religiosity relevant to the nineteenth century, and these still form the essence of portraits of the mysteries in contemporary scholarship. The mysteries were either examples of "personal religion" of "union with the deity" as answer to the decline in traditional religion, ${ }^{12}$ or a remnant of Roman Catholic-like ritualistic religiosity in an era of Protestant rationalism. ${ }^{13}$

A few examples of this enduring picture would suffice to demonstrate this trajectory:

The mystery cults of the Hellenistic-Roman world were a product of the age, a response to the changing attitudes of individual and social conditions. Both the oriental cults that had penetrated the

\footnotetext{
${ }^{11}$ For this discussion, I am drawing on material from my dissertation "Loose fictions and frivolous fabrications.' Ancient fiction and the mystery religions of the early Imperial Era" (Van den Heever 2005:27-36).

${ }^{12}$ The allusion to contemporary commentary on religion in nineteenth century Europe is unmistakeable.

${ }^{13}$ In J G Frazer's The golden bough: A study in magic and religion (originally appeared $1890 / 1900 / 1907-1915$, see the discussion in Smith, below) the putative decaying and revitalized vegetation - the vicissitudes of an incarnate "vegetative spirit" expressed in ritual was expressed in the myth of a dying and rising god and this formed the core of the myth and cult of such diverse cults as that of Osiris, Adonis, Thammuz, Attis, Dionysus; Egyptian, Syrian, Babylonian, Phrygian, and Greek religion. Although Christianity itself is rarely mentioned in a comparative manner in this context, yet running as an undercurrent to these studies, for Frazer Christianity shared the myth and the mystery rituals with these cults, and represented the growing accommodation of a once-pure Christianity with the pagan Umwelt "pagano-papist" apologetics: "Taken together, the coincidences of the Christian with the heathen festivals are too close and too numerous to be accidental. They mark the compromise which the Church in the hour of its triumph was compelled to make with its vanquished yet still dangerous rivals. The inflexible Protestantism of the primitive missionaries, with their fiery denunciations of heathendom, had been exchanged for the supple policy, the easy tolerance, the comprehensive charity of shrewd ecclesiastics ..." (Smith 1990:85-115, 116-144, the citation here from $\mathrm{p} 92 \mathrm{n}$ 14).
} 


\section{Undoing the sleights of hand}

Greek world and the old Greek cults were hellenized into mystery cults, mysteries, or mysteria, a Greek term that meant "initiation." The term was applied to the cults in which membership depended upon the participation of the initiate in a personal ritual that resulted in the individual's identification or close relationship with the deity of the cult ... [T]hree essential characteristics are common to all the mystery cults of the time: (1) a purification rite by which the initiate is granted admission and participation in the activity of the cult; (2) a sense of a personal relationship or communion with the deity or deities of the cult; and (3) the hope or promise of a life of blessedness after death. (my emphasis - GvdH)

(Tripolitis 2002:16-17)

At the end of her discussion of the mystery religions, Tripolitis would conclude that it was the universal and egalitarian character of the mysteries that accounted for their widespread popularity:

They were individualistic, addressing the spiritual needs of the individual, and they also provided the devotees with meaningful fellowship with individuals who possessed the same knowledge of salvation. Last, they provided a personal, closer relationship to the divine, protection from the adversities of this life, and the hope of some sort of blissful world after death. (my emphasis - GvdH)

(Tripolitis 2002:36)

In a similar vein, in his magisterial exposé of the Hellenistic age, Peter Green has argued in Alexander to Actium (Green 1990, esp 586-601): the mysteries of the Hellenistic-Roman era were part of an interconnected complex of phenomena such as the flourishing of "foreign cults," the flowering of oracles, astrology, and magic - the mysteries were symptomatic of a descent into the irrational. ${ }^{14}$ All these were epiphenomena of developments in the area of politics and society. As the city-states of classical antiquity lost their autonomy in the Hellenistic period, the experience of political impotence translated into personal surrender to superhuman power (whether political or transcendental in the form of Tyche, or other less elevated but no less malignant divine beings). But now, with the decline of the city-states of old also went hand in

\footnotetext{
${ }^{14}$ Green cites the famous work of E R Dodd, The Greeks and the irrational (originally published 1951) at the start of this section. The work of Dodd was immensely influential to a generation of scholars of Graeco-Roman religion, and his legacy endured even longer.
} 
hand the decline of traditional polis religion, ${ }^{15}$ and this opened the gate for a proliferation of private religious clubs and associations where the old polisderived identity was replaced by a new communal identity built on communal worship and shared banquets access to which was granted by initiation (Green 1990:589). In these kinds of Ersatz-communities the solitude of urban existence was exorcised in the exhilaration of emotional enthusiasm, ${ }^{16}$ in which salvation in the hereafter was promoted as remedy to the ills of this life (Green 1990:589). Together with magic, astrology, oracles, and epiphanies the mysteries constituted alternative societies, rites of passage into "the utopias of the desperate."17 Here again it is the socially constitutive function of the mysteries, but in its context conceived to be part of the slide into superstition, utopian fantasies, and the irrational, that is highlighted as the remedy for the lost individual in search of salvation.

In his overview of the Hellenistic world, F W Walbank (1992) too links the rise in mystery religions, and influx of oriental religions to socio-political developments.

But many new religious developments were a response to changes in individual attitudes and to new social conditions. With the reduced power of the city-states went a decline in men's confidence in their traditional cults and a growing interest in mystery religions and this was encouraged by a falling off in the rationalism that had been characteristic of much fifth-century sophistic thought. The mystery cults involved secret initiation ceremonies and promised individual salvation ... This trend towards revelation, irrational and emotional ... (my emphasis - GvdH).

(Walbank 1992:218)

\footnotetext{
15 "Were not the Olympian deities still officially worshipped? Did not every polis retain its traditional divine patron? All true; and yet the image had grown dead and hollow, eaten away at the heart by the boreworms of political impotence, creeping secularism, social fragmentation, loss of cohesive identity. Cities and empires had become too vast and heterogeneous to give adequate psychological support to inheritors of the old, local polis tradition: their society was no longer either integrated or manageable" (Green 1990:587).

16 "Indeed, the second century [BCE] (for reasons that by now should be clear enough) seems to have ushered in a general wave of religious emotionalism throughout the Mediterranean; if bien-pensant conservatives expressed shock, the poor, the desperate, and the dispossessed were (in every sense of the word) ecstatic. Initiatory rites for Isis, Mithras, and Cybele all seem to have been developed during the late Hellenistic period, at a time when, for an everincreasing proportion of the populace, bleak prospects on this earth made the promise of salvation in the hereafter look peculiarly attractive ..." (Green 1990:591-592).

17 "What is of rather more interest is the fact that such an elaborately traumatic enactment of rebirth should have found so ready a market. The age was hungry for visions, for miracles, for knowledge of what lay beyond the boundaries of nature and reason ..." (Green 1990:600, 595).
} 


\section{Undoing the sleights of hand}

And he continues: "More important to the ordinary man and woman were the oriental cults, especially those of Egypt, which increasingly penetrated the Greek world to fill the gap left by the collapse of belief in the indigenous gods ... In particular cults offering a personal contact with the divinity or the promise of personal survival after death were especially popular" (my emphasis GvdH) (Walbank 1992:220-221).

What is common to these kinds of conceptions of the mysteries are in the first instance the putative individualism characterising the mysteries, that is, their character as receptacles for alienated individuals; in the second place, their offering of salvation, conceived as (mostly but not exclusively) the overcoming of death; in the third place, union with divinity; and finally, their character as irrational, enthusiastic (or charismatic), and superstitious. Of course these portrayals of the mysteries did not suddenly appear out of nowhere, and for the purposes of this essay, this is the interesting and crucial question. These portrayals evidence the effective history of earlier scholarship on the mysteries, itself deeply implicated in the birth and rise of the study of religion as science. ${ }^{18}$ Gustav Anrich in his then groundbreaking work, delineated the 'religious meaning' of the mystery cults thus: the goal of the mysteries is the attainment of sōtēria guaranteed by the initiation rite, and this sōtēria consists of 'blessed immortality' in the afterlife, as well as a new life on earth in union with and under the protection of the particular deity (Anrich [1894] 1990:47). Next in importance to immortality is the idea of purification (Entsühnung/ Kathartik) effected in a wide variety of rituals from water lustrations to blood baptisms like the taurobolium and kriobolium (Anrich 1990:51-54). Essential to the initiation into the mystery is the fact that the mysteries do not only effect a subjective experience of unity with the divine, but the rite also effects the objective attainment of the realities constituting the sōtēria, so that the mystēs has now received the character indelebilis of sacratus, renatus, and tauroboliatus (Anrich 1990:54). ${ }^{19}$ The benefits accrued

\footnotetext{
${ }^{18}$ For a good overview of the rise of Religionswissenschaft, "Science of Religion," as a discipline and the effect of its embeddedness in European culture at the beginning of the nineteenth century on its origins, see Kippenberg (2002), as well as (among others of the included essays in the cited volume) Rudolph (1991), and Plantinga (1991). The discovery of irrationalism, the solitary individual, the identification of the mysteries as nature and vegetation religions, and the enthusiastic/ecstatic nature of this religiosity was, arguably, an epiphenomenon of the cultural period known as Romanticism. Although Romanticism as cultural movement lasted only about three decades up to about the 1830s, its effects were felt much longer. It can be argued that the picture of late Antiquity that emerged in scholarship and had become the standard portrayals by the end of the century, was the result of a romantic envisioning of the world.

${ }^{19}$ But note the unmistakeable influence of a Protestant interpretation of sacramental ritual in the differentiation between subjective experience and objective effect, the latter being evidence of a superstitious and magical view of ritual, characteristic of Catholicism, the direction into which the mysteries developed. The Catholic Church accommodated itself to late Antique religiosity as it became the state church.
} 
from initiation into a mystery do not preclude multiple initiation into other mysteries, the reason being the increasingly magical-superstitious view taken of the mysteries, which prompted the initiands to seek ever more secure guarantees for the sōtēria in multiple initiations and purifications (Anrich 1990:55). Lastly, Anrich highlights the development of religious, mystery communities as societies within society (Anrich 1990:56). Richard Reitzenstein added to these the interiorisation of the mysteries as a growing tendency towards the "faith" of mysteriosophy, ${ }^{20}$ and the increasing syncretism effected by the mysteries (Reitzenstein [1927] 1956:240-242).

The path to this construction of the mysteries was paved earlier in the nineteenth century. The emerging picture of the religious history of the ancient Near East was an answer to cultural, social, and political developments in Europe, especially Romanticism. ${ }^{21}$ Romanticism as style and as cultural movement itself was a reaction to two centuries of rationalism and increasing industrialisation. The alienation resulting from these social and political upheavals led to the birth of history in a two-fold sense: the birth of the modern scholarly discipline of history and history as a popular sense of a longing for a long-lost paradisal time of wholeness. ${ }^{22}$ On the plane of popular culture this ranged from rediscoveries of the "merrie England" of the Middle

\footnotetext{
${ }^{20}$ So clearly seen in the Hermetic and Gnostic material, the end point of the trajectory from Eleusis in classical Antiquity to the Gnosticism of late Antiquity, cf Reitzenstein ([1927] 1956:242-243). Again, the tendency is unmistakeable, the mysteries function as foil or counterpoint for the religio-historical conceptionalising of early Christianity, a point also underscored by Kippenberg (2002:118-119). In the history of religio-historical scholarship on early Christianity it is especially with reference to Paul and the Pauline tradition that the mystery religions have been useful as illuminating "background," see above. It is not difficult to understand why. The Pauline language of "mystery," the particular portrayal of baptism, and the complex of expressions of unity with Christ (in Christ, with Christ, etc) as dying with and rising with Christ, not to mention Pauline charismatic spirituality, have served as the justification for reading of the Pauline literature against the 'background' of both Gnosticism and mystery religions.

${ }^{21}$ I draw on the analysis of Fleming (1995:511-545).

${ }^{22}$ See Fleming (1995:543): "Above all, the romantic view included a sense of history. Creating imaginary places far apart from workaday situations proved a welcome refuge from the increasingly industrialized and mechanized world ... However, 'Any time but now, and any place but here' became the battle cries of romanticism." See also Plantinga (1991:157-158): "The primary characteristic of Romanticism, van der Leeuw thought, is longing (Verlangen), This continual and insatiable longing is for another world, for anything other present, condemning reality ... In thus holding that Romanticism and religion bear certain unmistakable resemblances, van der Leeuw meant that Romanticism and religion are similarly inclined to long for past golden ages and to dream of alternative realities and states. 'Es war sonst wirklich besser'. Homesickness and mourning for a past age are the fundamental Romantic feelings ... The search becomes restless, frenzied. The longing cannot be satisfied and thus tears become unavoidable and melancholy predominant. To alleviate the situation, the Romantic idealizes some place or state: Italy, India, the North America, fantasy worlds, the forest, night, the depths of the earth. Ultimately, the Romantic attempts to heal the brokenness and to satisfy the endless longing in his life by seeking an immediate unity, by seeking the infinite in the finite or the divine in nature" (my emphasis, GvdH).
} 


\section{Undoing the sleights of hand}

Ages (in fiction as well as in cultural movements such as the Arts and Crafts movement), to the wholesale revival of Gothic in architecture and literature, and followed by Romanesque, and Byzantine styles, as well as classical revivals of Greek and Roman styles. ${ }^{23}$ Simultaneously this period also saw the wholesale importation of the Orient into the "imaginative repertory" of the arts and architecture (Fleming 1995:534-535), and this at a time when discoveries in the field of archaeology and text collection and translation began to transport the exotic Orient into the historical scholarly consciousness of religious origins.

Apart from these developments, the period also saw the birth of the individual as hero: "Romantic social and political thought viewed the status of people as individuals first and foremost and as members of society secondarily. The romantic period was also the age of the emancipation of the individual and the era of the great hero attained such heights by personal efforts" (Fleming 1995:531). ${ }^{24}$ Finally, Romanticism also entailed the deification of nature in art as yet another way of expressing longing for the lost pastoral idyll (Fleming 1995:537). In religio-historical studies this found expression in the discovery of the category of salvation religion (Kippenberg 2002:120ff). Salvation religion was understood to indicate a kind of worldnegation (or Weltverneinung, as Hermann Siebeck formulated it) (Kippenberg 2002:121). In a context of the merging of Christianity with industrialised society, salvation religion became a culture-critical and philosophical term with which to postulate the autonomy of religion. As Kippenberg comments on Ernst Troeltsch: "Religion was thus something other than an ethical ideal; it was the basis of practiced subjectivity. The autonomy of religion and the irreducibility of the individual were two sides of the same coin. Only religion can protect culture from a permanent descent into materialism and save the human personality" (Kippenberg 2002:122-123) (my emphasis - GvdH). In these (re)constructions of mysteries religio-historical scholars constructed the mysteries of the Graeco-Roman world in terms of Romantic values. And furthermore, the more resolutely Christianity was interpreted as a historical phenomenon embedded in its contemporary context, the more its defining categories emerged in religio-historical view to express a distance from the world: eschatology, apocalypticism, mysticism, and asceticism (Kippenberg 2002:123).

\footnotetext{
${ }^{23}$ In part, the revival of Gothic was exactly in answer to the French empire of Napoleon, and formed the basis for a national English style, see Fleming (1995:544).

${ }^{24}$ Compare also: "All this was, perhaps, a positive assertion of the diminishing self in the face of a growing organization of society under collective control" (Fleming 1995:531). The artist as hero exemplified the importance of emotion over reason, of enthusiasm over restraint, of inspiration over rational argumentation.
} 
So here we have, in the worldview of Romanticism - in the lost and longing individuals, enthusiasm, irrationalism and possession, a return to nature as the fount of religion, a heightened clamour for the (distant) past the birth of the characteristic picture of the mysteries. As Plantinga (1991:159) says: "Given that the birth of the history of religion as a field of study followed not long after the demise of Romanticism in the nineteenth century, and that the former is in some sense a product of the latter, might there be more than an accidental relationship between the two?" All the famous names in the newly founded discipline of Religionsgeschichte were found in the gallery of Romanticism: Gerardus van der Leeuw, Johan Huizinga (Kuiper 1991), Schleiermacher, Max Müller, C P Tiele, Chantepie de la Saussaye, Nathan Söderblom, Rudolf Otto, Joachim Wach, and Friederich Heiler (Rudolph 1991:151-152), ${ }^{25}$ as well as the (eccentric and infamous) Jane Harrison (Schlesier 1991, esp pp 232-235). ${ }^{26}$

This was the context against which the work of figures such as $\mathrm{J} \mathrm{G}$ Frazer $^{27}$ and Otto Pfleiderer ${ }^{28}$ gain in significance. Both traced the origins of Mediterranean and oriental religions (and thus the mysteries) to an origin in vegetative religion of a dying and rising god as the expression of seasonal cycles of nature, and this view was hugely influential due to the influence of the Pan-Babylonian School at the beginning of the twentieth century. ${ }^{29}$

However much the ancient and classical mysteries may have been founded on such an originary myth expressing seasonal cycles in the metaphor of dying and rising gods (and this is not certain), the fact is - as

\footnotetext{
${ }^{25}$ The establishment of Science of Religion linked up with the theology of Schleiemacher: "Religionswissenschaft is zwar überlieferungskritisch in ihrer philologisch-historischen und quellenkritischen Methode, die mit entzaubernder Wirkung auf alle religiösen Dokumente, seien sie kanonischen oder heiligen Charakters, anwendet, aber in ideologischen Grundfragen ist sie theologisch oder religionsphilosophisch im eben genannten Sinne orientiert" Rudolph (1991:152). One can now immediately detect the origins of Otto's mysterium tremendum et fascinans, in fact, as Rudolph puts it, this provenance of Religionswissenschaft turned it into a theologia naturalis Rudolph (1991:154).
}

${ }^{26}$ Harrison played a leading role in the Myth and Ritual school, and was famous for her writings on the history of Greek religion, formulating a view of the origins of Greek religion and the mysteries in nature religion, or vegetative cults.

${ }^{27}$ In his oft-republished The golden bough.

${ }^{28}$ Various works: Das Christusbild des urchristlichen Glaubens in religionsgeschichtlicher Beleuchtung, and Die Entstehung des Christentums, and issued in English as well.

${ }^{29}$ The Pan-Babylonian School saw myth as essentially cyclical, following an "astronomical Babylonian pattern," or a "seasonal Canaanite pattern" Smith (1990:85-115). Hugely influential and hugely controversial: a history of scholarship in Christian history and New Testament literature was devoted to the refutation of these theories in order to insulate Christianity from these supposed influences or genealogical relations, the rhetorical techniques of which form the subject matter of Smith's (in itself hugely influential) book. 


\section{Undoing the sleights of hand}

Jonathan Z Smith so cogently argued, repeatedly - that the myths at issue are not static nor repetitions of the eternally recurring, to use a phrase made famous by Mircea Eliade. As narrative discourse qua form and narration they are inherently rhetorical, that is they are rhetorical interventions within particular contexts. ${ }^{30}$ And as, again qua Smith, we deal with religions in constant change and development, we are dealing in the imperial era with "archaic Mediterranean religions in their Late Antique phases," that is with "historical processes of reinterpretation, with tradition" (Smith 1990:106-107). Far from having in the mysteries a-historic religions with static worldviews and myth, we are looking at adapting traditions, the vicissitudes of gods and the ritual celebration of participation in these vicissitudes as products of the imperial era from the mid-first century onwards, and in the scholarly constructions of the historical phenomenon of the mysteries we similarly encounter these as products of nineteenth and early twentieth century mythmaking.

This last remark brings me back to the initial statement, and presupposition, this paper started from, namely that both the "original" religious production as a field of mythmaking, and scholarship on that religious production are social and political commentaries - are discourses in the sense I delineated before, and in this regard it is necessary to keep in mind that the two sets of examples - the cult of the Mother of the Gods/Cybele/Magna Mater, and the mysteries of the Graeco-Roman world - are indeed intimately linked in that the cult of Cybele/Magna Mater indeed featured large in the scholarly conceptualisation of the mysteries in nineteenth and twentieth century scholarship.

\section{WHERE THE TWO MYTHIC DISCOURSES MEET: THE FUNCTION OF SCHOLARSHIP}

While I have put the case for seeing both religious production and scholarship on religion as mythmaking endeavours, nevertheless, I also hold that the two are not simply identical, or at least, do not function on exactly the same level. Implied in Bruce Lincoln's "Theses on method" is the concept of distance, and this "distance" or distancing positioning towards religious production is the operative space for an interpretive analytic. The latter is, however, not

\footnotetext{
${ }^{30}$ See the critique of this type of explanation of myth and ritual in the essays of Jonathan $Z$ Smith, where he clearly overturns this view by showing how myths and rituals are to be understood as social performances grounded in, and elicited by, specific social circumstances. As Smith puts it in the Introduction to his essay volume Map is not territory (Smith 1978:xi): "I have come to insist that it is not sufficient to merely name a text; rather, it is necessary both to locate a text within a history of tradition and to provide some sort of explanation for the processes of continuity and change (my emphasis, GvdH)."
} 
understood as a decontextualised, disembodied, objective stance but as an intensely political participation in the construction of discourse (understood as the multileveled construction of lived reality and identity). Lincoln himself, in his recent work, has theorised the role of religious discourse as the hegemonic authorising institution in the triangulation with aesthetics (the field of value and taste) and morality (the field of practice) (Lincoln 2000:409-22; Lincoln 1998:55-69; Lincoln 2003, esp ch 4-6). In line with the history of the term "culture" in Western consciousness since the 18th century, but especially since the work of Matthew Arnold, "culture" is understood here as a site of social and political positioning, a site of contention, in other words: the political toil of imagining ourselves as positioned in a specific manner vis-á-vis all other imagined communities, and doing so drawing on a multitude of symbolic interventions in order to effect and maintain this positioning and identity. ${ }^{31}$

To put it simply: while we are all political agents, I now see the scholar of religion as a political commissar-cum-analyst-commentator, after the analogy of the authoritative sports commentator: while involved with the game and the public industry of the sport (and she/he may actually be quite a proficient player of the game), nevertheless as analyst-commentator does not take part in the game at hand itself. Rather, as biased ${ }^{32}$ analyst-commentator she/he shapes public construction of the event through analysis, explanation, and evaluation of the game, though filtered through his/her localised perspective and loyalties. It is because of these localised perspectives and loyalties (which guarantee the commentator's committed connection to the game) that the commentator enters the fray of constructing the game by adding an authoritative analytical voice to all the others, and in doing so, help make or break reputations, perceptions regarding proficiency and gamesmanship, and may even contribute in the long run to team selections and evolving game plans. Although I use the image of "authoritative analystcommentator", one should understand that "authoritative" is not an unproblematic or simple term to use in this connection. The "analystcommentator" is not authoritative simply by virtue of being a commentator. Authority needs to be constructed, and the analyst-commentator authorised in order to effectively play this political role I have sketched out above. ${ }^{33}$ Such

\footnotetext{
${ }^{31}$ On culture as a conflictual term (that is, denoting conflict), see (Eagleton 1983:24); Spillman (2002:1-16); in general the works of Bourdieu and Lincoln cited earlier.

${ }^{32}$ That is, referring to the political aspect.

${ }^{33}$ In Lincoln's book, Authority: Construction and Corrosion (Lincoln 1994), three authorising "media" are distinguished, namely authorising objects, times, and places which endow speakers and actors with authority to act and speak. In the metaphor employed here I have creatively played with these and contextualised them with a view to their use in my metaphor.
} 


\section{Undoing the sleights of hand}

authorising takes on multiple forms, from gaining expertise in the game and being recognised as expert (in the context of this discussion about religious scholarship, this would entail academic study and recognition as researcher), to occupying legitimised channels of communication (e.g., a nationally syndicated slot on some mass medium; or in the context of our discussion here, publishing in highly rated research publications, being variously deferred to as an expert in the field). Depending on which side of the dominant discourse about the field of the game the analyst-commentator finds $\mathrm{him} /$ herself, the commentator either constructs/maintains authority, or contributes to its corrosion, in which case the analyst-commentators functions as an agent provocateur.

Scholarship is also implicated in social formation, mythmaking, and worldview construction, or, after the above analogy - religious game-making. But what distinguishes scholarly production is the fact that, ideally, scholars make productive use of the distance towards the production of religion to which they are uniquely equipped, that is to say: "in" in an "out" manner, "out" in an "in" manner. In this sense the function of the scholar of religion is to denaturalise, demythologise, and demystify the discursive practices that led to the construction of religion or a specific religion as well as the discursive practices embodied in scholarly constructions, interpretations and theorising, or as is increasingly being asserted for the study of religion, to "historicise tradition" (see on this Engler \& Grieve 2005).

It is in the nature of religion as an ideology to hide its own rhetoricity or social interests. The scholar has to expose these (in the sense of illuminate, that is, bringing to light - making visible), for only then can a religious public ("religious game players") begin to truly understand what happens in the religious game and what religion does to them, and can they begin to accept responsibility for the religion they construct. This is best done by adopting a specific kind of "outsider viewpoint", namely that of a politically committed agent provocateur and saboteur, redescribing the phenomenon by means of foreign terminology and theoretical frameworks. ${ }^{34}$ Arguing like this resurrects the old debate of insider versus outsider viewpoints: which is to be privileged? As one starts to reflect on the new and radically different picture of Christian origins that is beginning to emerge in studies of early Christianity, it is clear that it is only once we cast off the legacy of the combined Luke/Acts-Eusebius portrait of early Christian history that real progress is made in accounting for the emergence and formation of Christianity as a historical phenomenon.

\footnotetext{
${ }^{34}$ I use the term "foreign", but extrinsic or etic would also do. "Foreign" at least has the ring of strangeness, over-the-horizonness, to it and as such implies much more of a distance than the rather abstract terms "extrinsic" or "etic". It is the distance I want to emphasise, "exaggerating here in the direction of truth."
} 
Earlier studies in church history were all beholden to the ideological interests of Christian imperial mythmaking, with all the disastrous effects this has on the history of the world and of humankind, so sharply described by Burton Mack (Mack 2001:177-193). Scholarship forbids insulating a historically privileged viewpoint from scrutiny.

In this regard, one cannot do scholarship on religion by avoiding questions of theory and discourse analysis, for since the past 30 years or so, all scholarship of necessity has to have the character also of metatheoretical reflection. One cannot read scholarly literature - and the Bible - as if the texts concur with the reality they speak about. All texts are essentially rhetorical interventions, which one needs to interpret before one can even begin to deal with the subject matter they speak about. Therefore, all scholarship moves by way of a dual procedure: to interpret the object as well as to interpret the interpretation of the object.

Thus, as a critical discourse, the field of scholarly production is an emancipatory project. While the conceptualisation underlying this paper is derived from Marxist studies and symbolic sociology, it is also closely related to Critical Theory and its aim of emancipation. Critical Theory became famous in the work of the so-called Frankfurt School (roughly late 1920s to 1960s in Germany and later elsewhere) and since the 1960s in the work of Jürgen Habermas. Described minimally as an interested "moment" in a transformative practice directed toward creating a more humane world, the aim of Critical Theory is to emancipate humans from the ideological distortions that enable the oppression of people. While classical Critical Theory shies away from providing a positive definition of the envisaged utopia (it is called "utopian pessimism") for the (good) reason that all erected utopias carry in themselves the propensity to renewed oppression, nevertheless the emancipatory function lies in its aim to inculcate critical discourse analysis in free social agents or social participants. What is meant by this? It is recognised that members of society are culturally programmed by cultural media and social institutions (or discursive formations) to be insensitised to injustice and unequal distributions of power and power-effects. Further, by means of what is called "technologisation" and "instrumentalisation" of reason, social participants are equipped to be proficient actors within the hegemonic confines of a particular cultural dispensation. Even scholarship is co-opted in the process by the establishment of canons of scholarship and validation processes that, while on the surface seemingly promoting deeply penetrating explorations and investigations, nevertheless serve to maintain the general uncritical acceptance of the cultural dispensation. Critical thinking and critique, in this context, means to theorise positionality in the unequal, multifariously structured dissipation of power and power-effects, and to theorise it in such a 


\section{Undoing the sleights of hand}

way as to bring to light the manner in which discourse as world-construction and the practices that flow from it, are results of ideologically laden, interested social positionality. The value of Critical Theory as a kind of discourse analysis, then, lies in its impulse towards enabling transcendence beyond the conditioning determinants of our social location and culture, it is a schooling beyond mere proficiency in achieving predetermined intellectual and practical goals. In this sense critique becomes a kind of activism, and for us, then, there is essentially no difference between theory and practice. ${ }^{35}$

Enfin, the toil of scholarly production finds its true value, I would contend, in enabling the exercise of responsible citizenship as free social agents.

\section{Works consulted}

Anrich, G 1990. Das antike Mysterienwesen in seinem Einfluß auf das Christentum. Hildesheim: Georg Olms.

Blake, N \& Masschelein, J 2003. Critical theory and critical pedagogy, in Blake, N Smeyers, P, Smith, R \& Standish, P (eds), The Blackwell guide to philosophy of education, 38-56. Maldon, MA: Blackwell. (Blackwell Philosophy Guides 9.)

Bourdieu, P 1968. Outline of a sociological theory of art perception. International Social Science Journal 20(4), 589-612.

Bourdieu, P 1977. Outline of a theory of practice, tr by R Nice. Cambridge: Cambridge University Press. (Cambridge Studies in Social and Cultural Anthropology 16.)

Bourdieu, P 1984. Distinction: A social critique of the judgement of taste, translated by R Nice. Cambridge, MA: Harvard University Press.

Bourdieu, P 1988. The historical genesis of a pure aesthetic. Journal of Aesthetics \& Art Criticism 46(3), 201-210.

Bourdieu, P 1990. The logic of practice. Cambridge: Polity Press.

Bourdieu, P 1992. Commentary on the commentaries. Contemporary Sociology $21(2), 158-61$.

Bourdieu, P 1993. The field of cultural production: Essays on art and literature, $\mathrm{tr}$ and ed by $\mathrm{R}$ Johnson. New York: Columbia University Press.

Eagleton, T 1983. Literary theory: An introduction. Oxford: Blackwell.

Engler, S \& Grieve, G P (eds) 2005. Historicizing "tradition" in the study of religion. Berlin: De Gruyter.

Fleming, W 1995. Arts and ideas. Fort Worth, TX: Harcourt Brace College.

Flood, G 1999. Beyond phenomenology: Rethinking the study of religion. London: Cassell.

Green, P 1990. Alexander to Actium: The Hellenistic age. London: Thames \& Hudson.

Griffith, P J 1999. Religious reading: The place of reading in the practice of religion. Oxford: Oxford University Press.

Hobsbawm, E 1983. Introduction: Inventing traditions, in Hobsbawm, E \& Ranger, T (eds), The invention of tradition, 1-14. Cambridge: Cambridge University Press.

\footnotetext{
${ }^{35}$ On this topic, see Blake \& Masschelein (2003:38-56).
} 
Kippenberg, H G 2002. Discovering religious history in the modern age. Princeton, $\mathrm{NJ}$ : Princeton University Press.

Kuiper, Y B 1991. The primitive and the past: Van der Leeuw and Huizinga as critics of culture, in Kippenberg, H G \& Luchesi, B (eds), Religionswissenschaft und Kulturkritik. Beiträge zur Konferenz: The history of religions and critique of culture in the days of Gerardus van der Leeuw (1890-1950), 113-125. Marburg: Diagonal-Verlag.

Lease, G 2000. Ideology, in Braun, W \& McCutcheon, R T (eds), Guide to the study of religion, 438-447. London: Cassell.

Limberis, V 1994. Divine heiress: The virgin Mary and the creation of Christian Constantinople. London: Routledge.

Lincoln, B 1983. The earth becomes flat: A study of apocalyptic imagery. Comparative Studies in Society and History 25(1), 136-153.

Lincoln, B 1994. Authority: Construction and corrosion. Chicago, IL: University of Chicago Press.

Lincoln, B 1998. Conflict, in Taylor, M C (ed), Critical terms for religious studies, 5569. Chicago, IL: University of Chicago Press.

Lincoln, B 1999. Theorizing myth: Narrative, Ideology and scholarship. Chicago, IL: University of Chicago Press.

Lincoln, B 2000. Culture, in Braun, W \& McCutcheon, R T (eds), Guide to the Study of Religion, 409-422. London: Cassell.

Lincoln, B 2003. Holy terrors: Thinking about religion after September 11. Chicago, IL: University of Chicago Press.

Lincoln, B 2005. Theses on method. Method \& Theory in the Study of Religion 17(1), 8-10.

Lincoln, B 2006. An early moment in the discourse of "terrorism": Reflections on a tale from Marco Polo. Comparative Studies in Society and History 42(2), 242259.

Mack, B L 2001. The Christian myth: Origins, logic, legacy. New York: Continuum.

Mali, J 2003. Mythistory: The making of a modern historiography. Chicago, IL: University of Chicago Press.

McNay, L 1999. Gender, habitus and the field: Pierre Bourdieu and the limits of reflexivity. Theory, Culture \& Society 16(1), 95-117.

Murphy, T 2000a. Discourse, in Braun, W \& McCutcheon, R T (eds), Guide to the study of religion, 396-408. London: Cassell.

Murphy, T 2000b. Speaking different languages: Religion and the study of religion, in Jensen, T \& Rothstein, M (eds), Secular theories on religion: Current perspectives, 183-192. Copenhagen: Museum Tusculanum.

Munn, M 2006. The Mother of the gods, Athens, and the tyranny of Asia: A study of sovereignty in ancient religion. Berkeley, CA: University of California Press. (A Joan Palevsky Book in Classical Literature.)

Plantinga, R J 1991. Romanticism and the history of religion: The case of W B Kristensen, in Kippenberg, H G \& Luchesi, B (eds), Religionswissenschaft und Kulturkritik: Beiträge zur Konferenz: The history of religions and critique of culture in the days of Gerardus van der Leeuw (1890-1950), 157-176. Marburg: Diagonal-Verlag.

Pye, $M$ 1973. Comparative hermeneutics in religion, in Pye, $M$ \& Morgan, $R$ (eds), The cardinal meaning: Essays in comparative hermeneutics: Buddhism and Christianity, 1-58. The Hague: Mouton. (Religion and Reason 6.) 


\section{Undoing the sleights of hand}

Pye, M 1994. Religion: Shape and shadow. Numen 41, 51-75.

Pye, M 2000. Westernism unmasked, in Jensen, T \& Rothstein, M (eds), Secular theories on religion: Current perspectives, 211-230. Copenhagen: Museum Tusculanum.

Reitzenstein, $\mathrm{R}$ 1956. Die hellenistischen Mysterienreligionen nach ihren Grundgedanken und Wirkungen. Stuttgart: Teubner.

Rudolph, K 1991. Die religionskritischen Traditionen in der Religionswissen-schaft, in Kippenberg, H G \& Luchesi, B (eds), Religionswissenschaft und Kulturkritik. Beiträge zur Konferenz: The history of religions and critique of culture in the days of Gerardus van der Leeuw (1890-1950), 149-156. Marburg: DiagonalVerlag.

Schlesier, R 1991. Prolegomena zu Jane Harrisons Deutung der antiken griechischen Religion, in Kippenberg, H G \& Luchesi, B (eds), Religionswissenschaft und Kulturkritik: Beiträge zur Konferenz: The history of religions and critique of culture in the days of Gerardus van der Leeuw (18901950), 193-235. Marburg: Diagonal-Verlag.

Smith, J Z 1978. Map is not territory, in Map is not territory: Studies in the history of religions, 289-309. Leiden: Brill. (Studies in Judaism in late Antiquity 23.)

Smith, J Z 1990. Drudgery divine: On the comparison of early Christianities and the religions of late antiquity. Chicago, IL: University of Chicago Press. (Chicago Studies in the History of Judaism.)

Spillman, L (ed) 2002. Cultural sociology. Malden, MA: Blackwell. (Blackwell Readers in Sociology.)

Tripolitis, A 2002. Religions of the Hellenistic-Roman age. Grand Rapids, MI: Eerdmans.

Turcan, R 1996. The cults of the Roman Empire, tr by Antonia Nevill. Oxford: Blackwell.

Van den Heever, G A 2005. Loose fictions and frivolous fabrications: Ancient fiction and the mystery religions of the early imperial era. PhD Dissertation. Pretoria: University of South Africa.

Van den Heever, G 1993. Die motief van die wêreldbrand: Zoroastrisme, formatiewe Judaïsme en vroeë Christendom: Patrone van interaksie. MTh thesis. Pretoria: University of South Africa.

Van den Heever, G 2004. Diversity: Religions and the study of religion. $R \& T$ 11(3\&4), 199-218.

Van den Heever, G 2007. Review of Mark Munn. The Mother of the Gods, Athens, and the tyranny of Asia: A study of sovereignty in ancient religion, Review of Biblical Literature [http://www.bookreviews.org] (21/7/2007).

Versnel, H S 1993. Inconsistencies in Greek and Roman Religion, I: Ter Unus, Isis, Dionysos, Hermes: Three studies in Henotheism. Leiden: Brill. (Studies in Greek and Roman Religion 6.1.)

Walbank, F W 1992. The Hellenistic world. London: Fontana. (Fontana History of the Ancient World.)

Wiebe, D 2001. Review essay: On religious studies and the rhetoric of religious reading. Method \& Theory in the Study of Religion 13, 344-351.

Wiebe, D 2006. An eternal return all over again: The religious conversation endures. Journal of the American Academy of Religion 74(3), 674-696. 